\title{
Information Transfers among Group-Affiliated Firms
}

\author{
Chunghuey Linda Huang \\ National Taipei University \\ E-mail: chuang@mail.ntpu.edu.tw \\ Hsiao-Yu Chang \\ Hong Yi Fiber Ind. Co., Ltd \\ E-mail: sandra@hongyilon.com.tw
}

\begin{abstract}
This study examines intra-group information transfers associated with quarterly earnings announcements. Specifically, the objectives of this paper are to investigate whether there is positive information transfers among group-affiliated firms, and to examine how the affiliate's operating strategy affect the extent of information transfers.

The sample includes 615 quarterly earnings releases by firms listed in Taiwan Stock Exchange between 1988 and 1997. The empirical results provide evidence of positive information transfers between affiliated firms associated with quarterly earnings announcements. In addition, the extent of information transfer is dependent on the diversification strategies of the group affiliates. When industry covariation in firms' returns is removed, directional information transfers remain significant.
\end{abstract}

Keywords: Group-affiliated Firms, Information Transfer, Quarterly Earnings Announcement, Market model, Two-index Model

\section{INTRODUCTION}

In the past half century the Asian economy experienced the greatest growth in the history. Many countries in the Pacific Rim enjoyed an average of $7 \%$ growth in real GDP per year since early 1990s. A significant part of the domestic and privately owned industrial sector, and particularly the activities which use relatively modern and capital-intensive techniques in many of those countries, is organized in a special 
institutional pattern, the "group" This pattern of economic organization is common in Asia and plays a central role in the development process. In Taiwan the total group affiliate's assets had increased tremendously from 0.3 trillion NT dollars in 1978 to 9.9 trillion NT dollars in 1997. Moreover, in the same period, the group affiliate's average total assets grew remarkably from 4.1 billion NT dollars to nearly 66.2 billion NT dollars. In 1997, total operating revenues from 154 group affiliates were nearly 4.36 trillion NT dollars, which accounted for more than 55\% of Taiwan's GNP. In 2001, total operating revenues from Big-100 business affiliates were nearly 8.15 trillion NT dollars, which accounted for more than $84 \%$ of Taiwan's GNP.

The group affiliate is a multi-company organization which transacts in different markets but which does so under common entrepreneurial and financial control. The affiliate draws its capital and its high-level managers from sources transcend a single family. It is a conglomerate of enterprises interlocked through direct family ownership and/or mutual shareholding among member firms. As such the performance of the member firms are highly correlated (Leff, 1978; Mok, 1992; Si, 1995).

Prior research on information transfer provides evidence consistent with a positive relation between the unsystematic stock returns of announcing and non-announcing firms at earnings releases ( Foster, 1981; Clinch and Sinclair, 1987; Baginski, 1987, 1989; Freeman, R. N. and Tse, S.,1992; Han et al., 1989; Han and Wild, 1990; Pownall and Waymire, 1989; Pyo and Lustgarten, 1990). Those results suggest that news releases of other firms within an industry are used in the determination of a given firm's security price.

Information transfers need not be confined to firms with similar production processes. The earnings release of one firm among affiliated firms may provide information that investors can use to revise their assessments of activities of other firms in the affiliate. To the extent that these activity projections are related to future cashflows and earnings, the new information embodied in one firm's earnings announcement will be incorporated into the other firms' security prices and the magnitude of stock reactions of other firms will be affected by the dependence between the announcing and non-announcing firms.

We find a positive relation between the contemporaneous unsystematic stock returns of announcing and non-announcing firms at earnings announcement dates. The results also show that the diversification strategies of the affiliates affect the extent of stock price covariations between announcing and non-announcing firms. The extent of information transfers is most significant for vertical and related business affiliates. It is weaker for unrelated business affiliate and the single business affiliate is the 
weakest. For unrelated business affiliate, the extent of information transfer is stronger when earnings releases are bad news than when the releases are good news. Overall, these findings suggest that announcing firm's financial reporting signal is useful in assessing the stock prices of other firms in the business affiliate.

Section 2 presents the research design, including the primary hypothesis, sample selection procedures, and definitions for key variables. Section 3 describes the empirical tests and results for information transfers. Concluding remarks are provided in section 4.

\section{HYPOTHESES AND SAMPLE SELECTION}

\section{Hypothesis Formulation}

The hypotheses tested in this study are similar to those in intra-industry information transfer studies. In null form, concerning the direction of the abnormal returns experienced by announcing and non-announcing firms, the first null hypothesis examined is that the sign of the abnormal return for non-announcing firm $\mathrm{j}$, conditional on the earnings release of firm i, is unrelated to the sign of firm i's abnormal return, firm $\mathrm{i}$ and $\mathrm{j}$ are in the same business affiliate. As the disclosure made by one firm may reflect economic conditions in which the firm operates as a whole. In other words, if the earnings release signals good news for the economic prospects, investors may become more optimistic about the other firms in the affiliate. Similar to Foster et al. (1984) assuming the market movements surrounding the earnings announcement reflect the sign of the news contained in the release, the alternative hypothesis is that the conditional abnormal return for non-announcing firm $\mathrm{j}$ is in the same direction as the abnormal returns of announcing firm. Denoting uj as a residual return metric for firm $\mathrm{j}$, this hypothesis may be stated formally as

$$
\begin{aligned}
& \text { H0 : } \mathrm{E}(\text { uj } \| \text { ui }>0 \text { or } u i<0)=0, \\
& \text { H1 : } \mathrm{E}(\text { uj } \| \text { ui }>0 \text { or } u i<0)>0 \text { or }<0 .
\end{aligned}
$$

Furthermore, the effect of information transfer among member firms in business affiliate could be related to the diversification strategy of the affiliate. Some affiliates diversify into vertically integrated or highly related business, while others may diversify into unrelated business or focus in single business (Rumelt, 1974). Affiliated firms vertically integrate their operations that will gain access to the upstream or downstream markets in order to diversify their business risk, to ensure material supplies, or to increase market shares. Consequently, earnings released by firms in 
highly integrated or related business affiliates could convey more information about the earnings of firms highly connected with the release firms in the affiliate. Therefore the second null hypothesis is that the effect of announcing firm's disclosure on non-announcing firms is unrelated to the strategy of diversification of the business affiliate.

\section{Sample Selection}

Preliminary quarterly earnings announcements are identified from the Data Bank of Taiwan Economic Journal for the ten-year period from January 1988 through December $1997^{1}$. To be included in the sample, the announcing firm must (1) belong to a business affiliate that has at least two member firms listed on the Taiwan Stock Exchange with calendar fiscal year, (2) be listed on the Taiwan Stock Exchange, (3) be the first announce its quarterly earnings, and (4) complete stock price data are available. These procedures yielded 629 earnings releases. All other firms in the same business affiliate as the forecast firms not releasing preliminary quarterly earnings announcements within two trading days of announcing firms are considered non-announcing firms. Firms are eliminated from the sample if (1) daily returns are unavailable from the Data Bank of Taiwan Economic Journal, and (2) insufficient returns exist for computing abnormal returns (section 2.3). The final sample of matched firms composed of 950 observations.

\section{Variable measurements}

\section{- Abnormal stock returns}

Estimates of abnormal stock returns for announcing and non-announcing firms at earnings release dates are obtained using the market model:

$$
A R_{i, t}=R_{i, t}-E\left(\hat{\alpha}_{i}+\hat{\beta}_{i} R_{m, t}\right)
$$

where $R_{i t}$ is the daily stock return for firm $i$ on day t, and $R_{m t}$ is the value-weighted market index for day t. The model's parameters, $\alpha$ and $\beta$ are estimated using OLS; the estimation period extends from the preceding two hundred trading days through three trading days prior to the earnings announcement date. The abnormal returns are then summed up the during event period as Cumulative abnormal returns $\left(\mathrm{CAR}_{\mathrm{it}}\right)$

\footnotetext{
${ }^{1}$ Prior to 1988 only few business affiliates have member firms more than two listed in the Taiwan Stock Exchange.
} 


\section{- Business affiliates}

The identification of business affiliates is adopted from the study by China Credit Information Service (CCIS) in 1998. A business affiliate is composed of three or more related corporations that mutually acknowledge their common membership and have both combined sales and total assets of at least NT $\$ 400$ million or the sum of combined sales and total assets of more than 1 billion. For each business affiliate, there is usually an identifiable core company and the corresponding core family. For a firm to be considered as a affiliate member, it should satisfy either of the following criteria. First, the core company or core owner's family owns more than 50\% or the majority of the firm's outstanding shares. Second, more than $25 \%$ of the firm's outstanding shares are mutually held. Third, more than half of the board members, executive shareholders and general managers are the same as those of the core company, or the board members in the firm and in its core company are interlocking or are relatives. Fourth, member firms are under the common control of core company.

\section{- Diversification Strategies}

The absence of markets for risk and uncertainties of instability and rapid structural change in the early development stage causes the affiliates' expansion in diversified product lines (Leff, 1978). Vertical integration has been sought to avoid being dependent on a monopolist or oligopolist for raw materials, or on an oligopsonist for the affiliate's products. In other cases, new investments may be made in product markets that are unrelated but in activities where the affiliate's technical and managerial capabilities are applicable as inputs. Nevertheless, the affiliates usually exercise a considerable degree of market power in the activities where they operate.

Our measure of diversification strategy is a slight modification of those defined and tested in Rumelt (1974). Taking a business unit to be a product, product line, or set of product lines that have strong market interdependencies, a firm's specialization ratio, Rs, is the fraction of revenues accounted for by its largest single business unit. The related ratio, $\mathrm{Rr}$, is the fraction of a firm's revenues attributable to its largest affiliate of related businesses. Finally, a firm's vertical ratio Rv is the fraction of its revenues attributable to its largest affiliate of products, joint-products, and by-products associated with the processing of a raw material through a set of stages. Note that Rs < $\mathrm{Rv} \leqq \mathrm{Rr}$. Then business affiliates are categorized as follows: 
Vertical business affiliate: $\quad \mathrm{Rv} \geqq 0.7$

Single business affiliate: $\quad$ Rs $\geqq 0.7$

Related business affiliate: $\mathrm{Rs}<0.7 ; \mathrm{Rr} \geqq 0.7$

Unrelated business affiliate: $\mathrm{Rs}<0.7 ; \mathrm{Rr}<0.7$

\section{EMPIRICAL RESULTS}

The empirical results demonstrate that there are information transfers associated with quarterly earnings announcements released by member firms in business affiliates as evidenced by the daily abnormal returns of non-announcing affiliates in Table 1.

Table 1 Daily and cumulative abnormal returns for non-announcing member firms (Total samples) ( Total Samples) $\mathrm{n}=932$

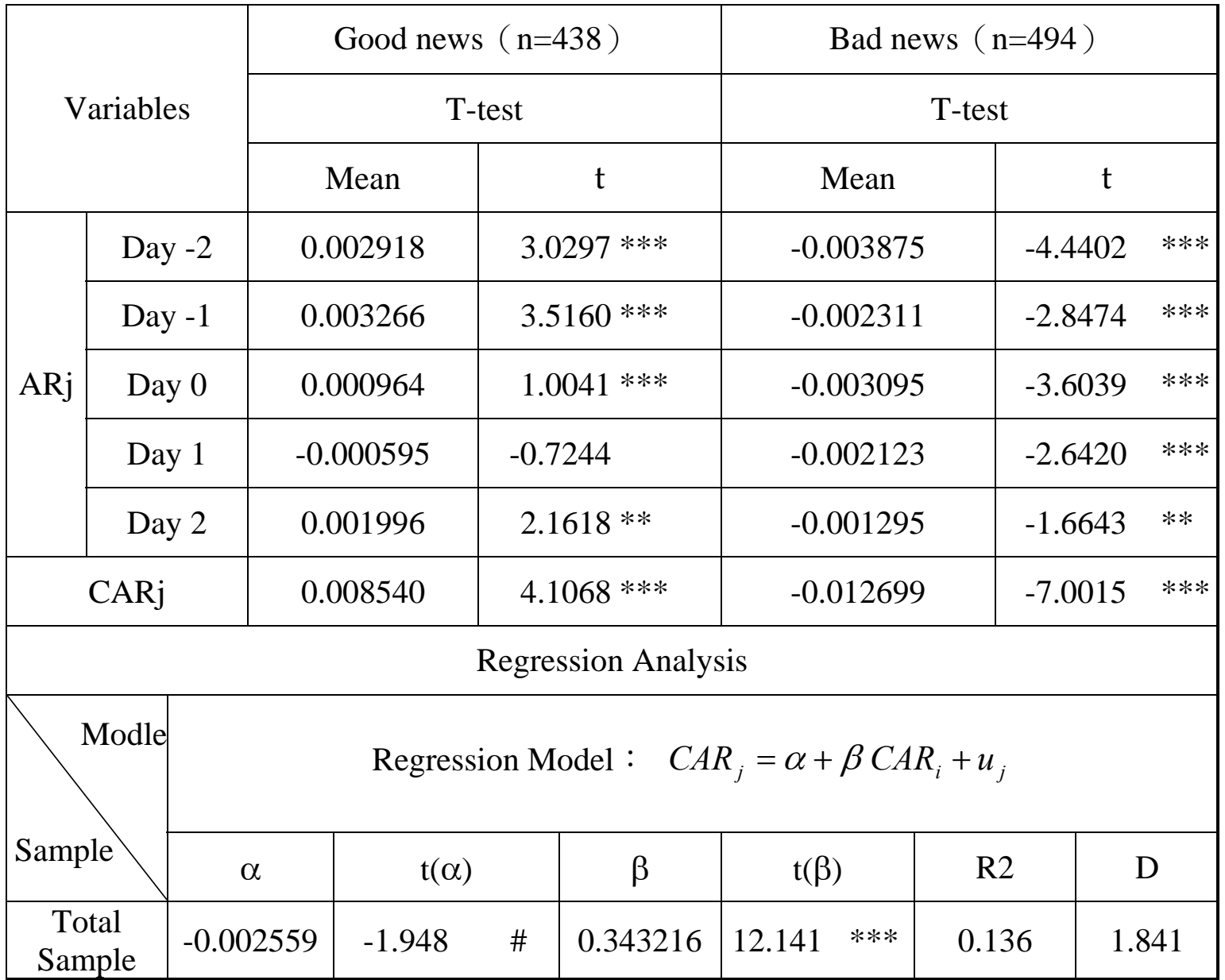

ARj : Average abnormal returns (\%)

CARj : Cumulative Average Abnormal Returns (\%)

*,**,*** 10\%, 5\%, 1\% significance levels (One-tailed)

\# $\quad 10 \%$ significance levels (Two-tailed) 
To examine the differential impact of affiliate diversification strategy on the extent of intragroup information transfer, we divide our sample into four affiliates: vertical, single business, related, and unrelated business affiliates Table 2 indicates that, except for single business affiliate, the directional intragroup information transfers are apparent for affiliates with different diversification strategies. However, unlike the results obtained for the total sample, we find that the differential information transfers for bad and good news only exist in affiliates with unrelated diversification strategies.

Table 2 Intra-group Information Transfers for affiliates with Different Diversification Strategies

\begin{tabular}{|c|c|c|c|c|c|c|c|}
\hline \multirow{2}{*}{ CAR } & \multicolumn{3}{|c|}{ Good news } & \multicolumn{4}{|c|}{ Bad news } \\
\hline & Sample & Mean & T-test & Sample & Mean & \multicolumn{2}{|c|}{ T-test } \\
\hline Vertical & 94 & 0.011854 & $2.6494 * * *$ & 71 & -0.020251 & \multicolumn{2}{|c|}{$-4.6421 * * *$} \\
\hline Single & 33 & 0.002736 & 0.3952 & 29 & -0.010313 & \multicolumn{2}{|l|}{-1.1435} \\
\hline Related & 119 & 0.011519 & $2.7359 * * *$ & 141 & -0.017252 & \multicolumn{2}{|c|}{$-4.5139 * * *$} \\
\hline Unrelated & 192 & 0.006068 & $1.9677 * *$ & 253 & -0.008316 & \multicolumn{2}{|c|}{$-3.5999 * * *$} \\
\hline \multicolumn{8}{|c|}{ Regression Analysis } \\
\hline & \multicolumn{7}{|c|}{ Regression Model : $\quad C A R_{j}=\alpha+\beta A R_{i}+u_{j}$} \\
\hline Sample & $\alpha$ & $\mathrm{t}(\alpha)$ & $\beta$ & \multicolumn{2}{|c|}{$\mathrm{t}(\beta)$} & R2 & $\mathrm{D}$ \\
\hline Vertical & -0.003588 & -1.206 & 0.490936 & \multicolumn{2}{|c|}{$7.179 * * *$} & 0.236 & 2.217 \\
\hline Single & -0.004405 & -0.791 & 0.227167 & \multicolumn{2}{|c|}{$1.665 *$} & 0.028 & 2.432 \\
\hline Related & -0.002651 & -0.994 & 0.374356 & \multicolumn{2}{|c|}{$7.950 * * *$} & 0.194 & 1.611 \\
\hline Unrelated & -0.001951 & -1.068 & 0.266221 & \multicolumn{2}{|c|}{$6.044 * * *$} & 0.074 & 1.807 \\
\hline
\end{tabular}

ARj : Average abnormal returns(\%)

CARj : Cumulative Average Abnormal Returns(\%)

Vertical business affiliate: $\mathrm{Rv} \geqq 0.7$.

Single business affiliate: $\mathrm{Rs} \geqq 0.7$.

Related business affiliate: $\mathrm{Rs}<0.7 ; \mathrm{Rr} \geqq 0.7$.

Unrelated business affiliate: $\mathrm{Rs}<0.7 ; \mathrm{Rr}<0.7$.

*,**,*** 10\%, 5\%, 1\% significance levels (One-tailed )

\#,\#\#,\#\#\# 10\%, 5\%, 1\% significance levels (two-tailed ) 
To further investigate the relative strength of information transfers among those affiliates, we add a dummy variable for affiliate identity in the regression model. Table 3 shows that the extent of information transfer is marginally greater for vertical business affiliate than for related business affiliate. The extent of information transfer for unrelated business affiliate is weaker than those two affiliatess.

Table 3 Relative Information Transfers of Vertical, Related and Unrelated GroupAffiliates

\begin{tabular}{|c|c|c|c|c|c|c|c|c|c|c|}
\hline & \multicolumn{2}{|c|}{$\alpha 1$} & \multicolumn{2}{|l|}{$\alpha 2$} & \multicolumn{2}{|c|}{$\beta 1$} & \multicolumn{2}{|c|}{$\beta 2$} & \multirow[t]{2}{*}{$\mathrm{R} 2$} & \multirow[t]{2}{*}{$\mathrm{D}$} \\
\hline & Mean & $\mathrm{t}$ - test & Mean & $t$ - test & Mean & $\mathrm{t}$ - test & Mean & $\mathrm{t}$ - test & & \\
\hline $\begin{array}{l}\text { Vertical } \\
\text { v.s. } \\
\text { Relateda } \\
(n=425)\end{array}$ & -0.002651 & -1.038 & -0.000937 & -0.229 & 0.374356 & $8.296 * * *$ & 0.116581 & 1.348 & 0.207 & 1.785 \\
\hline $\begin{array}{c}\text { Vertical } \\
\text { v.s. } \\
\text { Unrelateda } \\
(\mathrm{n}=610)\end{array}$ & -0.001951 & -1.072 & -0.001637 & -0.467 & 0.266221 & $6.062 * * *$ & 0.224715 & 2.749 \#\#\# & 0.122 & 1.899 \\
\hline $\begin{array}{c}\text { Related } \\
\text { v.s. } \\
\text { Unrelatedb } \\
(\mathrm{n}=705)\end{array}$ & -0.001951 & -1.024 & -0.000700 & -0.223 & 0.266221 & $5.794 * * *$ & 0.108134 & $1.698 \quad \#$ & 0.128 & 1.725 \\
\hline
\end{tabular}

CARj : Cumulative Average Abnormal Returns (\%)

Vertical business affiliate: $\mathrm{Rv} \geqq 0.7$.

Single business affiliate: Rs $\geqq 0.7$.

Related business affiliate: Rs $<0.7 ; \mathrm{Rr} \geqq 0.7$.

Unrelated business affiliate: $\mathrm{Rs}<0.7 ; \mathrm{Rr}<0.7$.

a(b) : $\mathrm{Gi}=1$, if firmi belongs to vertical (related) business affiliate; $\mathrm{Gi}=0$, otherwise $*, * *, * * * 10 \%, 5 \%, 1 \%$ significance levels (One-tailed )

\# $\quad 10 \%$ significance levels (Two-tailed )

Han, Wild and Ramesh (1989) demonstrate that the observed intra-industry information transfers become insignificant after controlling for industry and market in measuring abnormal stock returns. To investigate whether our results are attributed to industry effect, we repeat our analyses using two-index model. Table 4 shows that the directional informational transfers are still significant for the whole sample after controlling for both market and industry movements. Table 5 indicates that when firms release good news, stock prices of non-announcing firms in the vertical or 
unrelated business affiliates react positively, while stock prices of non-announcing firms in the single or related business affiliates react indifferently. On the other hand, when firms release bad news, stock prices of non-announcing firms in the vertical, single or related business affiliates react negatively, while stock prices of non-announcing firms in the unrelated business affiliates react indifferently. Regression analyses indicate that the intra-group information transfers are still significant for each diversification affiliate except for single business affiliate. Overall our findings suggest that under common control affiliate member firms' stock prices are closely associated even after the removal of industry covariation.

Table 4 Daily and Cumulative Abnormal Returns for Non-announcing Member Firms (Using Two-index Model, Total Samples )

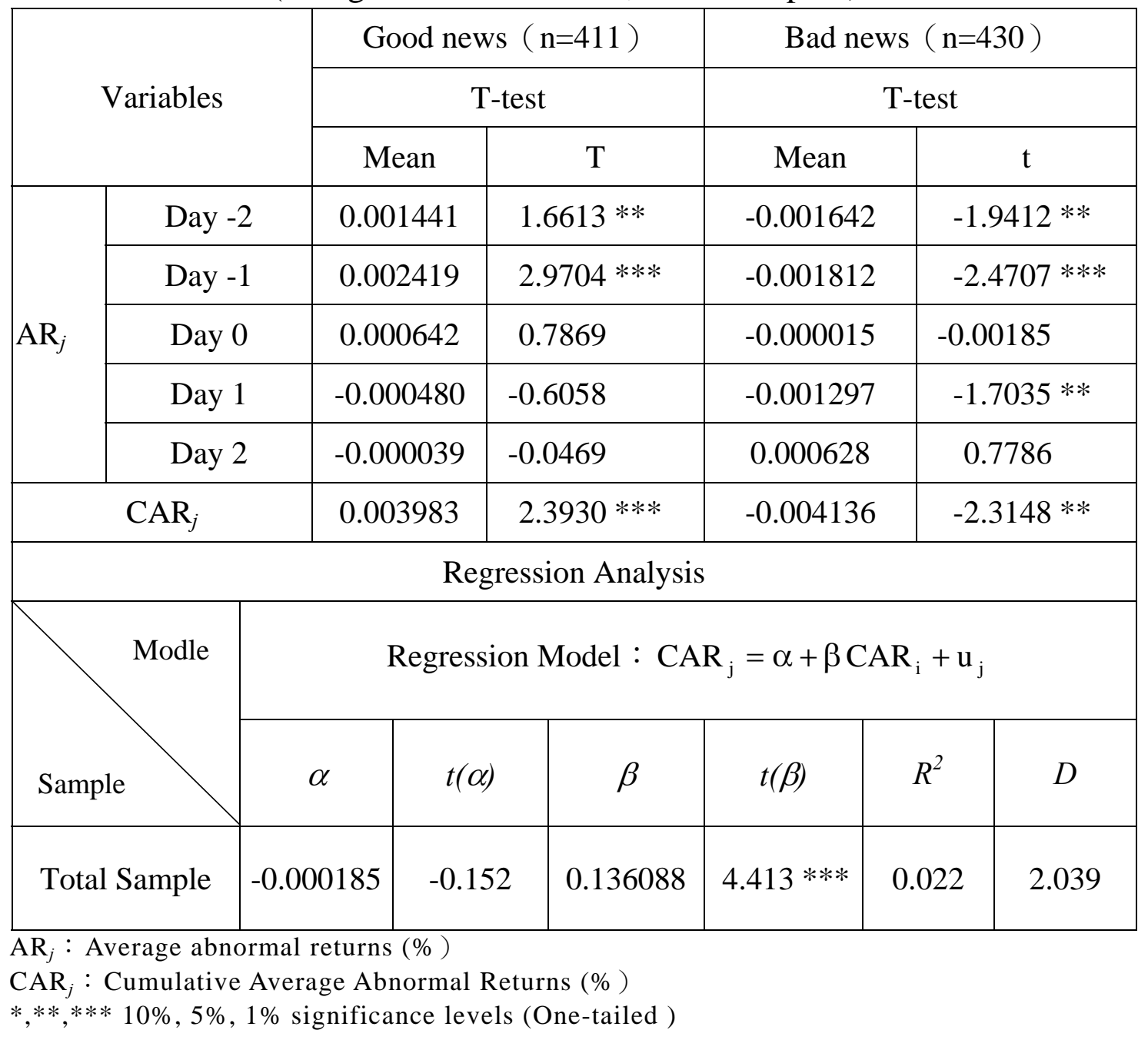


Finally, we examine the stock reactions of non-affiliate firms in the same industry as non-announcing firms with similar sizes. Vertical and related business affiliates having the greatest information transfers are selected for investigation. Table 6 indicates that the cumulative abnormal returns are insignificant for non-affiliate firms and no directional information transfers are observed, which further confirm our findings that affiliate membership plays an important role in determining the stock prices of member firms.

Table 5 Cumulative Abnormal Returns for Non-announcing Member Firms (Using Two-index Model)

\begin{tabular}{|c|c|c|c|c|c|c|c|c|c|c|}
\hline \multirow{2}{*}{ CAR } & \multicolumn{5}{|c|}{ Good news } & \multicolumn{5}{|c|}{ Bad news } \\
\hline & Sample & \multicolumn{2}{|c|}{ Mean } & \multicolumn{2}{|c|}{ T-test } & \multicolumn{2}{|c|}{ Sample } & Mean & \multicolumn{2}{|c|}{ T-test } \\
\hline Vertical & 80 & \multicolumn{2}{|c|}{0.010938} & \multicolumn{2}{|c|}{$2.8652 * * *$} & \multicolumn{2}{|c|}{83} & -0.007384 & \multicolumn{2}{|c|}{$-1.8075 * *$} \\
\hline Single & 33 & \multicolumn{2}{|c|}{0.005500} & \multicolumn{2}{|c|}{0.8842} & \multicolumn{2}{|c|}{29} & -0.009180 & \multicolumn{2}{|c|}{$-1.5798 *$} \\
\hline Related & 111 & \multicolumn{2}{|c|}{-0.000864} & \multicolumn{2}{|l|}{-0.2741} & \multicolumn{2}{|c|}{112} & -0.005168 & \multicolumn{2}{|c|}{$-1.4747 *$} \\
\hline Unrelated & 187 & & 3616 & \multicolumn{2}{|c|}{$1.4821 *$} & \multicolumn{2}{|c|}{206} & -0.001557 & \multicolumn{2}{|c|}{-0.5919} \\
\hline \multicolumn{11}{|c|}{ Regression Analysis } \\
\hline Moc & \multicolumn{10}{|c|}{ Regression Model : $C A R_{j}=\alpha+\beta A R_{i}+u_{j}$} \\
\hline Sample & \multicolumn{2}{|l|}{$\alpha$} & \multicolumn{2}{|c|}{$t(\alpha)$} & \multicolumn{2}{|c|}{$\beta$} & \multicolumn{2}{|r|}{$t(\beta)$} & $R^{2}$ & $D$ \\
\hline Vertical & \multicolumn{2}{|c|}{0.00142} & \multicolumn{2}{|c|}{0.509} & \multicolumn{2}{|c|}{0.27928} & \multicolumn{2}{|c|}{$3.514 * * *$} & 0.066 & 2.089 \\
\hline Single & \multicolumn{2}{|c|}{-0.00211} & \multicolumn{2}{|c|}{-0.481} & \multicolumn{2}{|c|}{0.15380} & \multicolumn{2}{|c|}{1.213} & 0.008 & 2.336 \\
\hline Related & -0.0026 & & -1.1 & & 0.12 & & & $369 * * *$ & 0.002 & 1.857 \\
\hline Unrelated & 0.0008 & & 0.4 & & 0.09 & & & $977 * *$ & 0.007 & 2.030 \\
\hline
\end{tabular}

$\mathrm{AR}_{j}$ : Average abnormal returns (\%)

$\mathrm{CAR}_{j}$ : Cumulative Average Abnormal Returns (\%)

$*, * *, * * * 10 \%, 5 \%, 1 \%$ significance levels (One-tailed)

\section{CONCLUSION}

In sum, we find that intra-group information transfers do exist among firms in group affiliates in Taiwan. Moreover, the stock returns of announcing firms' earnings releases are positively correlated with non-announcing firms' stock price movements. The nature of news and the type of diversification strategy affect differentially the extent of information transfers of earnings announcements between announcing and non-announcing firms. When industry covariation in firms' returns is removed, directional information transfers remain significant. 
Table 6 Cumulative Abnormal Returns of Non-affiliated Firms

\begin{tabular}{|c|c|c|c|c|c|c|c|c|c|c|}
\hline \multirow{2}{*}{ CAR } & \multicolumn{5}{|c|}{ Good news } & \multicolumn{5}{|c|}{ Bad news } \\
\hline & Sample & \multicolumn{2}{|c|}{ Mean } & \multicolumn{2}{|c|}{ T-test } & Sample & \multicolumn{2}{|c|}{ Mean } & \multicolumn{2}{|c|}{ T-test } \\
\hline Vertical & 182 & \multicolumn{2}{|c|}{-0.239585} & \multicolumn{2}{|c|}{0.773} & 138 & \multicolumn{2}{|c|}{-0.429013} & \multicolumn{2}{|c|}{-1.2551} \\
\hline Related & 205 & \multicolumn{2}{|c|}{0.002772} & \multicolumn{2}{|c|}{0.8048} & \multicolumn{3}{|c|}{-0.000217} & \multicolumn{2}{|c|}{-0.0723} \\
\hline \multicolumn{11}{|c|}{ Regression Analysis } \\
\hline & \multicolumn{10}{|c|}{ Regression Model : } \\
\hline Samnle & \multicolumn{2}{|l|}{$\alpha$} & \multicolumn{2}{|c|}{$t(\alpha)$} & \multicolumn{2}{|c|}{$\beta$} & $t(\beta)$ & \multicolumn{2}{|c|}{$R^{2}$} & $D$ \\
\hline Vertical & \multicolumn{2}{|c|}{-0.331721} & \multicolumn{2}{|c|}{-1.442} & \multicolumn{2}{|c|}{0.0044429} & 0.800 & \multicolumn{2}{|c|}{0.002} & 1.859 \\
\hline Related & \multicolumn{2}{|c|}{0.129133} & \multicolumn{2}{|c|}{0.569} & \multicolumn{2}{|c|}{0.039292} & 1.003 & \multicolumn{2}{|c|}{0.000} & 1.672 \\
\hline
\end{tabular}

ARj : Average abnormal returns(\%)

CARj : Cumulative Average Abnormal Returns(\%)

Vertical business affiliate : $\mathrm{Rv} \geqq 0.7$.

Related business affiliate : Rs $<0.7 ; \mathrm{Rr} \geqq 0.7$.

$*, * *, * * * 10 \%, 5 \%, 1 \%$ significance levels (One-tailed)

\section{REFERENCE}

Baginski, S. P. (1987). Intraindustry Information Transfers Associated with Management Forecasts of Earnings. Journal of Accounting Research, 25(2), Autumn, 196-216.

Baginski, S. P. (1989). Management Forecasts and Release-Specific Directional Information Transfer. Quarterly Review of Economics and Business, 29(4), Winter, 49-62.

Clinch, G. J., \& Sinclair, N. A. (1987). Intra-Industry Information Releases : A Recursive Systems Approach. Journal of Accounting and Economics, 9(1), 89-106.

Dyer, J. C., \& Mchugh, A. J. (1975). The Timeliness of the Australian Annual Report. Journal of Accounting Research, Autumn, 13(2), 204-219.

Foster, G. (1981). Intra-Industry Information Transfers Associated with Earnings Releases. Journal of Accounting and Economics, 3(3), 201-232.

Foster, G., Olsen, C., \& Shevlin, T. (1984). Earnings Releases, Anomalies and the Behavior of Security Returns. The Accounting Review, 59(4), 574-603. 
Freeman, R. N., \& Tse, S. (1992). An Earnings Prediction Approach to Examining Intercompany Information Transfers. Journal of Accounting and Economics, 15(4), 509-523.

Han, J. C. Y., Wild, J. J., \& Ramesh, K. (1989). Managers' Earnings Forecasts and Intra-Industry Information Transfers. Journal of Accounting and Economics, 11(1), 3-33.

Han, J. C. Y.,\& Wild J. J. (1990). Unexpected Earnings and Intraindustry Information Transfers : Further Evidence. Journal of Accounting Research, Spring, 28(1), 211-219.

Leff, N. (1978). Industrial Organization and Entrepreneurship in the Developing Countries: the Economic Groups. Economic Development and Cultural Change, 26, 661-675

Mok, H. M. K., Lam, K., \& Cheung, I. (1992, January). Family Control and Return Covariation in Hong Kong's Common Stocks. Journal of Business Finance and Accounting, 19(2), 277-293.

Pownall, G., \& Waymire, G. (1989). Voluntary Disclosure Choice and Earnings Information Transfer. Journal of Accounting Research, 27, 85-110.

Pyo, Y., \& Lustgarten, S. (1990). Differential Intra-Industry Information Transfer Associated with Management Earnings Forecasts. Journal of Accounting and Economics, 13, 365-379.

Rumelt, P. P. (1974). Diversfication Strategy and Profitability. Strategic Management Journal, 3, 359-369

Si, H. (1995). A Research in the Association of Stock Returns of Conglomerate. Unpublished master thesis, National Taiwan University. 